\title{
Peer Support Interventions for Adults With Diabetes: A Meta-Analysis of Hemoglobin $\mathrm{A}_{1 \mathrm{c}}$ Outcomes
}

\author{
Sonal J. Patil, MD, MSPH \\ Todd Ruppar, PbD, RN, GCNS-BC ${ }^{2}$ \\ Richelle J. Koopman, MD, MS ${ }^{1}$ \\ Erik J. Lindbloom, MD, MSPH \\ Susan G. Elliott, MLS ${ }^{1}$ \\ David R. Mebr, MD, MS ${ }^{1}$ \\ Vicki S. Conn, PbD, RN, FAAN ${ }^{2}$ \\ 'Department of Family and Community \\ Medicine, University of Missouri, Colum- \\ bia, Missouri \\ ${ }^{2}$ Sinclair School of Nursing, University of \\ Missouri, Columbia, Missouri
}

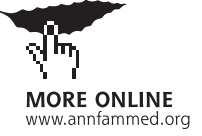

Conflicts of interest: authors report none.

\section{CORRESPONDING AUTHOR}

Sonal J. Patil, MD

Curtis W. and Ann H. Long Department of Family and Community Medicine MA306 Medical Sciences Building, DC032.00

University of Missouri

Columbia, MO 65212

patilso@health.missouri.edu

\begin{abstract}
PURPOSE Peer support intervention trials have shown varying effects on glycemic control. We aimed to estimate the effect of peer support interventions delivered by people affected by diabetes (those with the disease or a caregiver) on hemoglobin $A_{1 c}\left(H_{b A_{1 c}}\right)$ levels in adults.
\end{abstract}

METHODS We searched multiple databases from 1960 to November 2015, including Ovid MEDLINE, the Cochrane Central Register of Controlled Trials, CINAHL, and Scopus. We included randomized controlled trials (RCTs) of adults with diabetes receiving peer support interventions compared with otherwise similar care. Seventeen of 205 retrieved studies were eligible for inclusion. Quality was assessed with the Cochrane risk of bias tool. We calculated the standardized mean difference (SMD) of change in $\mathrm{HbA}_{1 c}$ level from baseline between groups using a random effects model. Subgroup analyses were predefined.

RESULTS Seventeen studies ( 3 cluster RCTs, 14 RCTs) with 4,715 participants showed an improvement in pooled $\mathrm{HbA}_{\mathrm{lc}}$ level with an SMD of $0.121(95 \% \mathrm{Cl}$, $0.026-0.217 ; P=.01 ; I^{2}=60.66 \%$ ) in the peer support intervention group compared with the control group; this difference translated to an improvement in $\mathrm{HbA}_{1 \mathrm{c}}$ level of $0.24 \%$ (95\% Cl, 0.05\%-0.43\%). Peer support interventions showed an $\mathrm{HbA}_{1 \mathrm{c}}$ improvement of $0.48 \%\left(95 \% \mathrm{Cl}, 0.25 \%-0.70 \% ; P<.001 ; \mathrm{I}^{2}=17.12 \%\right)$ in the subset of studies with predominantly Hispanic participants and $0.53 \%$ $\left(95 \% \mathrm{Cl}, 0.32 \%-0.73 \% ; P<.001 ; \mathrm{I}^{2}=9.24 \%\right)$ in the subset of studies with predominantly minority participants; both were clinically relevant. In sensitivity analysis excluding cluster RCTs, the overall effect size changed little.

CONCLUSIONS Peer support interventions for diabetes overall achieved a statistically significant but minor improvement in $\mathrm{HbA}_{1 c}$ levels. These interventions may, however, be particularly effective in improving glycemic control for people from minority groups, especially those of Hispanic ethnicity.

Ann Fam Med 2016;14:540-551. doi: 10.1370/afm.1982.

\section{INTRODUCTION}

7 he global burden of diabetes is expected to increase from 381.8 million people affected in 2013 to an estimated 591.9 million by 2035. ${ }^{1}$ Despite increasing evidence of benefits from self-management education, only $5 \%$ of Medicare-insured and $7 \%$ of privately insured people with diabetes receive this intervention within 1 year of diagnosis. ${ }^{2-4}$ Diabetes self-management education improves hemoglobin $\mathrm{A}_{\mathrm{lc}}\left(\mathrm{HbA}_{\mathrm{lc}}\right)$ levels, and longer duration of education further lowers levels; however, the benefits decline 1 to 3 months after education ends. ${ }^{5}$

The World Health Organization (WHO) has stated that peer support appears to be a promising approach to improving and sustaining diabetes self-management behaviors. ${ }^{6}$ Randomized controlled trials (RCTs) using peer support interventions delivered by people affected by diabetes have shown varying results on glycemic control, however. A 2012 narrative review examined the effect of peer support interventions on diabetes outcomes, but several additional studies with these interventions have been published in the last 3 years. ${ }^{7}$ One recent meta-analysis looked at peer support for improv- 
ing glycemic control, yet this analysis included trials with community health workers and bilingual clinic employees as peer health coaches and was missing a few intervention trials that used people affected by diabetes as peer supporters. ${ }^{8}$ Hence, to date, there has not been an adequate systematic review and meta-analysis of the overall effectiveness of peer support interventions delivered by people affected by diabetes to inform policy or potential health care delivery changes.

We therefore performed a systematic review and meta-analysis of RCTs to assess the effectiveness of peer support interventions on improving glycemic control in adults with diabetes as measured by $\mathrm{HbA}_{1 \mathrm{c}}$ levels compared with counterparts who received otherwise similar care except for the peer-delivered interventions. The American Academy of Family Physicians (AAFP) program Peers for Progress defines peer support as "support from a person who has knowledge from their own experiences with diabetes, a person with diabetes, or a person affected by diabetes (eg, immediate family member or caregiver)." ${ }^{\prime 9}$ We used this definition in our study as our goal was to estimate the effect of training and engaging people affected by diabetes to improve glycemic control of others affected by the disease. Qualitative evaluations have suggested that being a peer supporter makes people feel more empowered to manage their own diabetes. ${ }^{10}$ Hence, peer support interventions delivered by affected individuals seems like a promising method to engage primary stakeholders in their diabetes self-management.

\section{METHODS}

We used the PRISMA (Preferred Reporting Items for Systematic Reviews and Meta-Analyses) statement along with the PRISMA explanation and elaboration document to report our findings. ${ }^{11}$ Methods of analysis, inclusion criteria, outcome of interest, and data extraction were predefined.

\section{Search Strategy and Study Selection}

We included only RCTs that compared peer support interventions with otherwise similar care in adults with diabetes that measured $\mathrm{HbA}_{1 \mathrm{c}}$ level as a primary or secondary outcome. We allowed any duration of follow-up. As noted above, the AAFP Peers for Progress definition was used to define peer support as support from a person with or affected by diabetes. ${ }^{9}$ Any peer-delivered interventions designed to improve self-management or health behaviors, or to provide emotional or social support with the goal of improving overall health were eligible. We included studies if both the peer intervention group and the control group received similar baseline education from diabetes educators and similar baseline care management from health care professionals.
To avoid contamination of the peer support intervention effect, we excluded studies providing additional health professional-delivered intervention or education other than that provided by peers in the intervention group compared with the control group; also excluded were studies of support groups or peer interactions facilitated by professionals other than peer supporters. We additionally excluded studies comparing a peer-delivered intervention with an identical one delivered by other community or health professionals, as the goal of this analysis was to look at the additional effect on glycemic control of peer-delivered interventions compared with otherwise similar care.

\section{Data Sources}

We searched English and non-English articles from January 1960 through November 2015 using Ovid MEDLINE, the Cochrane Central Register of Controlled Trials, the Cochrane Database of Systematic Reviews, CINAHL, PsycINFO, Scopus, OCLC First Search, ProQuest Dissertations \& Theses A\&I, BioOne Abstracts and Indexes, Social Service Abstracts, and Sociological Abstracts. Groups of search terms included diabetes mellitus ${ }_{i} \mathrm{HbA}_{1 \mathrm{c} i}$ peer support, peer educator, peer coach; promotora; and RCT. (See Supplemental Appendix A1 for the detailed search strategy for MEDLINE, http:// www.annfammed.org/content/14/6/540/suppl/DC1.)

We also conducted searches of Scopus, CINAHL, PsycINFO, and Google Scholar for eligible studies by authors with known expertise in peer support research. We reviewed the AAFP Peers for Progress website, the WHO statement on peer support in diabetes management, and references in published articles for any additional studies. Authors of eligible conference submissions identified through the OCLC PapersFirst database were contacted for further information to ascertain whether their study met our inclusion criteria. Two reviewers (S.J.P. and R.J.K.) independently screened citations, and all selections were reviewed by 2 additional reviewers (T.R. and V.S.C.) to confirm their suitability.

\section{Quality Assessment}

Two authors (S.J.P. and E.J.L.) assessed study quality independently using the Cochrane Collaboration's risk of bias tool and checked for interrater comparability. ${ }^{12}$ Only trials reporting $\mathrm{HbA}_{1 \mathrm{c}}$ level as an outcome were included in this review; hence, the risk of selective data reporting was considered minimal.

\section{Data Extraction}

A codebook was created before data extraction to include all variables of interest and predefined subgroups by 1 author (S.J.P.) and was reviewed by 3 other authors (E.J.L., T.R., and V.S.C.). Data were 
extracted independently by 2 authors (S.J.P. and E.J.L.) who discussed all disagreements and resolved them to achieve $100 \%$ consensus. One additional author (T.R.) confirmed the extraction accuracy of numerical outcome data.

We extracted data on study setting and multiple participant and peer characteristics. For intervention characteristics, we extracted method of intervention, planned sessions, number of successful intervention contacts, hours of training for peer supporters, and components of the peer support intervention. We coded peer supervision as present if the peer-delivered sessions were observed or recorded, if participants' knowledge was assessed after peer supporters delivered education sessions, if a contact log between peer supporters and participants was maintained, if calls were recorded, or if participants were contacted to determine whether peer supporters had been in contact with them. Support and guidance for peer supporters was not coded as peer supervision. If necessary information was not reported in published articles, we contacted authors to obtain it. We extracted $\mathrm{HbA}_{1 \mathrm{c}}$ values and measures of statistical variation at baseline and at study conclusion.

\section{Data Synthesis and Analysis}

Statistical analysis was performed using Comprehensive Meta-analysis Software version 3 (Biostat Inc). We calculated the standardized mean difference (SMD) in changes from baseline $\mathrm{HbA}_{1 \mathrm{c}}$ level to end-of-study level between the peer support intervention and control groups to adjust for varying baseline $\mathrm{HbA}_{1 \mathrm{c}}$ level. If reported, intention-to-treat data were used without adjusting for missing data or losses to follow-up. To compute effect sizes, we used the random-effects model of DerSimonian and Laird ${ }_{1}^{13}$ as it provides more conservative estimates by incorporating both withinand between-study variation. We calculated an SMD effect size (Cohen $d$ ), which reflects the difference in means between treatment and control participants in terms of their shared SD. ${ }^{14}$ We calculated $95 \% \mathrm{CIs}$, and we considered a $P$ value of $<.05$ statistically significant for all analyses other than the Q statistic. Corrected sample size was calculated for cluster randomized trials using the documented intracluster coefficient. ${ }^{15} \mathrm{We}$ assumed a correlation coefficient of 0.5 between initial and final values as recommended by Follmann and colleagues. ${ }^{16}$ Heterogeneity among studies was evaluated by the $Q$ statistic with a $P$ value of $<.10$ indicating heterogeneity and by the $\mathrm{I}^{2}$ statistic. $\mathrm{I}^{2}$ values of less than $40 \%$ may indicate insignificant heterogeneity; $30 \%$ to $60 \%$ may indicate moderate heterogeneity $y_{i} 50 \%$ to $90 \%$ may indicate substantial heterogeneity $y_{i}$ and $75 \%$ to $100 \%$ indicates considerable heterogeneity. ${ }^{17}$
Using analysis of variance (ANOVA) for mixed effects analysis to assess effect sizes, we performed predefined subgroup analyses for studies grouped by predominant participant ethnicity (that seen in $\geq 50 \%$ of participants), predominant participant minority status, peer intervention methods, control group interventions, and presence of peer supervision. The fixed effect $Q$ statistic was used to determine statistical significance of the difference of effects between subgroups. ${ }^{18}$ We performed metaregression analyses to assess effects of baseline $\mathrm{HbA}_{1 \mathrm{c}}$ level, duration of peer training in hours, and duration of observation on study effect sizes. Publication bias was assessed using a funnel plot and using the Egger regression test. ${ }^{19}$

\section{RESULTS}

\section{Study Selection}

We retrieved 400 citations from our database searches and database author searches. After removing duplicates and reviewing abstracts, we examined 36 full articles. Figure 1 shows the literature search flow diagram and reasons for article exclusions. ${ }^{20}$ Ultimately, 14 articles with RCT designs and 3 cluster RCTs were eligible for inclusion in the meta-analysis, for a total of 4,715 participants. Of the 17 trials, 10 were done in the United States, ${ }^{21-30} 4$ in Europe, ${ }^{31-34} 1$ in Canada ${ }^{35} 1$ in China, ${ }^{36}$ and 1 in Argentina. ${ }^{37}$ Study characteristics are shown in Table 1. Most of the trials included lifestyle counseling, goal setting, and behavioral and social support as peer support interventions.

\section{Risk of Bias and Publication Bias}

An assessment of quality for all included studies is shown in Table 2, with details given in Supplemental Appendix Table A1 (http://www.annfammed.org/content/14/6/540/suppl/DC1). In all but 4 of the 17 trials (23.5\%), the dropout rate was less than $20 \%{ }^{21,27,33,35}$ None of the trials blinded participants, but 3 trials (17\%) blinded outcomes assessors or investigators. Allocation concealment was not reported in 3 studies and not done in 1 study. We found no association between quality of studies and outcomes. Neither the funnel plot (Supplemental Appendix Figure A1, http://www.annfammed.org/content/14/6/540/suppl/DC1) nor the Egger regression test $(P=.47)$ suggested publication bias.

\section{Effect on $\mathrm{HbA}_{1 \mathrm{c}}$ Level}

The overall pooled effect of peer support interventions on $\mathrm{HbA}_{1 \mathrm{c}}$ level from the random effects model was an SMD of 0.121 (95\% CI, 0.026-0.217; $P=.01$ ) (Figure 2). This difference translates to an improvement in $\mathrm{HbA}_{1 \mathrm{c}}$ level of $0.24 \%$ (95\% CI, $0.05 \%-0.43 \%)$ in peer support intervention groups compared with the control 
groups, where the pooled mean $\mathrm{HbA}_{1 \mathrm{c}}$ level was $8 \%$. The $\mathrm{I}^{2}$ was $60.66 \%$, indicating moderate heterogeneity. A sensitivity analysis excluding cluster RCTs showed a similar pooled effect, with an SMD of 0.137 (95\% CI, 0.021-0.254; $\left.P=.02 ; \mathrm{I}^{2}=66.03 \%\right)$, which translates to an improvement in $\mathrm{HbA}_{1 \mathrm{c}}$ level of $0.27 \%$ (95\% CI, 0.04\% 0.5\%) (Supplemental Appendix Figure A2, http://www. annfammed.org/content/14/6/540/suppl/DC1).

\section{Subgroup Analyses}

\section{Studies With Ethnic or Racial Predominance}

The pooled effect of peer support interventions in the subgroup of 5 studies with predominantly Hispanic participants showed a clinically relevant and statistically significant SMD of 0.241 (95\% CI, 0.126-0.355; $P<.001$; $\left.\mathrm{I}^{2}=17.12 \%\right)$, which translates to an improvement in $\mathrm{HbA}_{1 \mathrm{c}}$ level of $0.48 \%$ (95\% CI, $0.25 \%-0.70 \%$ ) in the peer support intervention group compared with the control group (Figure 3). ${ }^{21,26,27,30,37}$ In contrast, the pooled effect size from the 7 studies with predominantly white, non-Hispanic participants showed no improvement in $\mathrm{HbA}_{1 \mathrm{c}}$ level with peer support interventions, with an SMD of -0.004 (95\% CI, -0.153 to $0.144 ; P=.95$; $\left.\mathrm{I}^{2}=59.41 \%\right) .{ }^{22,25,29,31-34}$ The pooled effect in the subgroup of 3 studies with predominantly African American participants showed a similar effect size to that seen in the Hispanic subgroup but was not statistically significant, with an SMD of 0.25 (95\% CI, -0.064 to $\left.0.571 ; P=.11 ; \mathrm{I}^{2}=58.60 \%\right) .{ }^{23,24,28}$ The differences in effect sizes between ethnicity subgroups were statistically significant, with a between-group $P$ value of .03 .

Considering together the 7 studies with predominantly minority participants (belonging to minority culture in the country of residence), the pooled effect showed a clinically relevant improvement in $\mathrm{HbA}_{1 \mathrm{c}}$ level with peer support interventions, with an SMD of $0.266(95 \% \mathrm{CI}$, $\left.0.163-0.369 ; P<.001 ; \mathrm{I}^{2}=9.24 \%\right)$, which translates to improvement in $\mathrm{HbA}_{1 \mathrm{c}}$ level of $0.53 \%(95 \% \mathrm{CI}$,
$0.32 \%-0.73 \%$ ) (Figure 4 ). In the 9 studies with predominantly nonminority participants, the pooled effect size showed no improvement in $\mathrm{HbA}_{1 \mathrm{c}}$ level with peer support interventions, with an SMD of -0.002 (95\% $\mathrm{CI},-0.109$ to $\left.0.106 ; P=.97 ; \mathrm{I}^{2}=45.90 \%\right)$. The betweengroup difference based on minority status was statistically significant, with a $P$ value of .001 . One study did not report the ethnic distribution of its participants ${ }^{34}$ and was excluded from the ethnicity- and minoritybased subgroup analysis.

Studies With Baseline Education or Care Management In 5 studies, both control and intervention groups received diabetes education classes or care manage-

\section{Figure 1. Results of the literature search.}

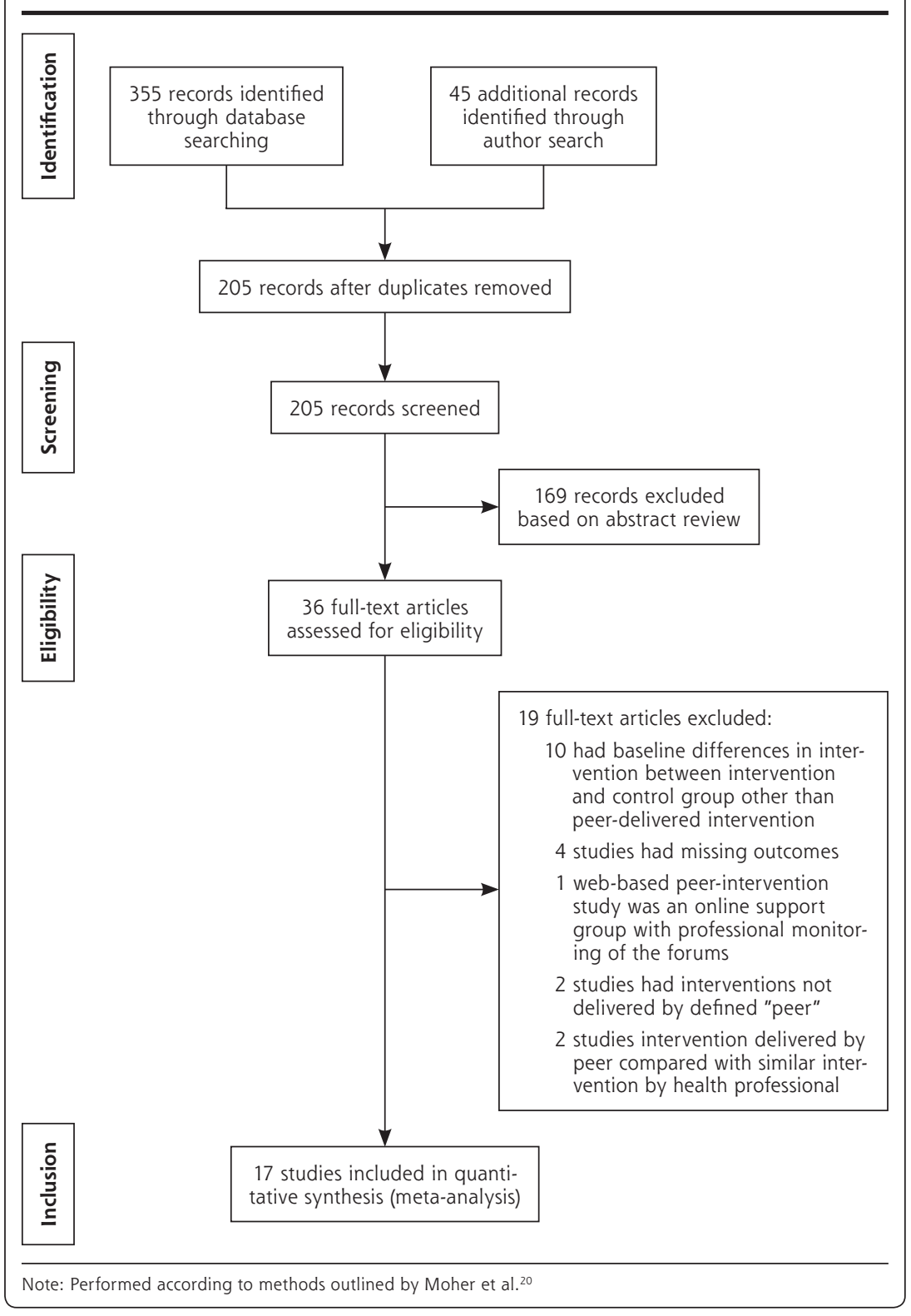


Table 1. Descriptive Summary of the Characteristics of Included Studies

\begin{tabular}{|c|c|c|}
\hline Study, Year & $\begin{array}{l}\text { Patients, } \\
\text { No. }\end{array}$ & Setting, Population \\
\hline \multirow[t]{2}{*}{$\begin{array}{l}\text { Keyserling et al, }{ }^{23} \\
2002\end{array}$} & \multirow[t]{2}{*}{133} & $\begin{array}{l}\text { United States: African } \\
\text { American women }\end{array}$ \\
\hline & & Mean $\mathrm{HbA}_{1 \mathrm{c}} 11.1 \%$ \\
\hline \multirow[t]{2}{*}{$\begin{array}{l}\text { Lorig et al, } 26 \\
\quad 2008\end{array}$} & \multirow[t]{2}{*}{417} & $\begin{array}{l}\text { United States: Spanish- } \\
\text { speaking patients }\end{array}$ \\
\hline & & Mean $\mathrm{HbA}_{1 c} 7.41 \%$ \\
\hline \multirow[t]{2}{*}{$\begin{array}{l}\text { Lorig et al, }{ }^{25} \\
\quad 2009\end{array}$} & \multirow[t]{2}{*}{345} & $\begin{array}{l}\text { United States: white, non- } \\
\text { Hispanic patients } 67 \%\end{array}$ \\
\hline & & Mean $\mathrm{HbA}_{1 \mathrm{c}} 6.72 \%$ \\
\hline \multirow[t]{2}{*}{$\begin{array}{l}\text { Dale et al, } \\
2009\end{array}$} & \multirow[t]{2}{*}{187} & $\begin{array}{l}\text { United Kingdom: white, } \\
\text { non-Hispanic patients } \\
96.65 \%\end{array}$ \\
\hline & & Mean $\mathrm{HbA}_{1 c} 8.55 \%$ \\
\hline \multirow[t]{2}{*}{$\begin{array}{l}\text { Cade et al, } \\
\quad 2009\end{array}$} & \multirow[t]{2}{*}{207} & $\begin{array}{l}\text { United Kingdom: white, } \\
\text { European-origin patients } \\
95 \%\end{array}$ \\
\hline & & Mean $\mathrm{HbA}_{1 \mathrm{C}} 7.4 \%$ \\
\hline \multirow[t]{2}{*}{$\begin{array}{l}\text { Heisler et al, }{ }^{22} \\
2010\end{array}$} & \multirow[t]{2}{*}{244} & $\begin{array}{l}\text { United States: Male veterans, } \\
\text { white non-Hispanic } 82 \%\end{array}$ \\
\hline & & Mean $\mathrm{HbA}_{1 c} 7.97 \%$ \\
\hline \multirow[t]{2}{*}{$\begin{array}{l}\text { Philis-Tsimikas } \\
\text { et al, }{ }^{27} \text { t2011 }\end{array}$} & \multirow[t]{2}{*}{207} & $\begin{array}{l}\text { United States: Mexican } \\
\text { Americans }\end{array}$ \\
\hline & & Mean $\mathrm{HbA}_{1 c} 10.4 \%$ \\
\hline \multirow[t]{4}{*}{$\begin{array}{l}\text { Smith et al, } \\
2011\end{array}$} & \multirow[t]{4}{*}{388} & $\begin{array}{l}\text { Republic of Ireland: Cluster } \\
\text { randomized }\end{array}$ \\
\hline & & $50 \%$ population low income \\
\hline & & $\begin{array}{l}\text { Ireland general demographics } \\
94.3 \% \text { white non-Hispanic }\end{array}$ \\
\hline & & Mean $\mathrm{HbA}_{1 c} 7.2 \%$ \\
\hline \multirow[t]{2}{*}{$\begin{array}{l}\text { Long et al, }{ }^{24} \\
2012\end{array}$} & \multirow[t]{2}{*}{77} & $\begin{array}{l}\text { United States: African } \\
\text { American veterans }\end{array}$ \\
\hline & & Mean $\mathrm{HbA}_{1 \mathrm{c}} 9.85 \%$ \\
\hline \multirow[t]{2}{*}{$\begin{array}{l}\text { Gagliardino } \\
\text { et al, } \\
2013\end{array}$} & \multirow[t]{2}{*}{198} & $\begin{array}{l}\text { Argentina: Hispanic, } \\
\text { nonminority in country } \\
\text { of residence }\end{array}$ \\
\hline & & Mean $\mathrm{HbA}_{1 c} 7.2 \%$ \\
\hline \multirow[t]{2}{*}{$\begin{array}{l}\text { Siminerio et } \text { al, }^{29} \\
2013\end{array}$} & \multirow[t]{2}{*}{68} & $\begin{array}{l}\text { United States: white non- } \\
\text { Hispanic ethnicity }>80 \%\end{array}$ \\
\hline & & Mean $\mathrm{HbA}_{1 \mathrm{c}} 8.65 \%$ \\
\hline \multirow[t]{2}{*}{$\begin{array}{l}\text { Thom et al, }{ }^{30} \\
2013\end{array}$} & \multirow[t]{2}{*}{299} & $\begin{array}{l}\text { United States: Hispanic } \\
\text { 46.65\%, African American } \\
31.25 \% \text {; coded as predomi- } \\
\text { nantly Hispanic }\end{array}$ \\
\hline & & Mean $\mathrm{HbA}_{1 \mathrm{c}} 9.95 \%$ \\
\hline \multirow[t]{2}{*}{$\begin{array}{l}\text { Chan et al, } \\
\quad 2014\end{array}$} & \multirow[t]{2}{*}{628} & $\begin{array}{l}\text { China: Chinese speaking } \\
\text { 100\% }\end{array}$ \\
\hline & & Mean $\mathrm{HbA}_{1 \mathrm{c}} 8.2 \%$ \\
\hline
\end{tabular}

Intervention

Same as control; also 3 group sessions and monthly telephone calls from a peer counselor for $12 \mathrm{mo}$

7 peer counselors for 67 patients

6-wk program:

$2.5 \mathrm{~h}$ weekly led by 2 peer leaders

2 peers per 10-15 patients

6-wk program:

$2.5 \mathrm{~h}$ weekly led by 2 peer leaders

2 peers per 10-15 patients

Peer supporter called participants after

change in their diabetes care at days 7-10,

$14-18,28-35,56-70,120-150$

1 peer called median of 10 patients

Peer educators delivered 2 -h education sessions per week for $7 \mathrm{wk}$

5 peer educators for 86 participants

Peer partners encouraged to call weekly

Three optional 1.5-h face-to-face sessions at 1,3 , and 6 mo

Weekly 2.5 -h education sessions by peer educators for 8 wk

9 peer supporter-facilitated sessions over $2 \mathrm{y}$; at mo 1, at mo 2, and every 3 mo thereafter

Weekly telephone calls by peer mentors; 34 mentors and 39 participants

4 weekly peer educator sessions of 90-120 min initially; 1 at 6 mo followed by weekly calls for 6 mo then biweekly calls for 3 mo

Additional face-to-face visits among peers and their supportees were scheduled every second month if specific issues warranted

Same as control followed by monthly peer calls for 6 mo for diabetes self- management support

Telephone contacts with peers at least twice a month and 2 or more in-person contacts in $6 \mathrm{mo}$

Coaches worked with median of 7 patients

Same as control and peer supporter telephone calls: biweekly for $3 \mathrm{mo}$, then monthly for $3 \mathrm{mo}$, and then 1 call every other month for 6 mo; anticipated 15 min per call

Peer-led group education sessions once a month for at least $5 \mathrm{mo}$ and telephone/ e-mail for 1:1 counseling
Control

Individual counseling visits with nutritionist at mo 1 , 2,3 , and 4

Usual care

Usual care

Usual care

Usual care

Usual care

Usual care

Usual care

Usual care

4 weekly sessions of 90-120 min initially:

1 at 6 mo by educators

6 wk of CDE diabetes selfmanagement education intervention

Usual care

Comprehensive assessment personalized report, $2-h$ nurse-led empowerment class, follow-up primary care visit with repeated laboratory assessment and mailing of follow-up reports

Usual care
England: Cluster randomizeo factorial design; white,
non-Hispanic $>90 \%$

Mean $\mathrm{HbA}_{1 \mathrm{c}} 7.3 \%$

$\mathrm{CDE}=$ certified diabetes educator; $\mathrm{Hb}_{1 \mathrm{c}}=$ hemoglobin $\mathrm{A}_{1 \mathrm{c}}$. 


\section{Duration of Peer Training}

$16 \mathrm{~h}$

$24 \mathrm{~h}$

2-d training program developed for the study

Residential training course provided by the Expert Patients Programme of the National Health Service

Initial 1.5 -h training in peer communication skills

$40 \mathrm{~h}$ of training, plus trainees cotaught 2 series of classes with their trainer and taught 2 series on their own, under observation by the trainer

Two 3-h evening training sessions conducted by research teams

Single 1-h one-on-one training session

3-d intensive, structured, small group interactive course

1-d peer training workshop for CDE with companion workbook- CDE then trained peers in 2-3-h small sessions

$36 \mathrm{~h}$ of training over $8 \mathrm{wk}$ in either English or Spanish

Four 8-h training sessions

Main training $14 \mathrm{~h}$ plus $3.5 \mathrm{~h}$ diabetes education session

\section{Peer Supervision}

None reported

Random observations

Random observations

None reported

None reported

Interactive voice response-facilitated telephone platform recorded call initiation, frequency, and duration

Classes were audio-recorded and reviewed using checklists

Meetings were recorded

No supervision

Diabetes knowledge of participants tested with multiple-choice questionnaire

Contact logs for communications; goal selections were tracked

Not reported

Peer supporter completed and mailed checklists to document discussion items, duration of each call, and relevant remarks every 3 mo

\section{Attendance Rates, Intensity}

$81 \%$ of participants attended at least 1 peer counselor session, $30 \%$ attended 2 sessions, and $19 \%$ attended 3 sessions

Average phone calls per participant: 9.7

Not reported

Mean attendance of 4.9 of 6 sessions

Mean number of calls each patient received: 4.5

(range $=1-6$ calls; SD, 2.2)

Of 110 participants in intervention group, 18 attended only 1 session and 22 attended all 7 sessions

63 participants attended final diabetes-specific session

$90 \%$ of peer pairs had at least 1 conversation; average number of calls per pair per month was $2.4,1.7,1.4,1.0,0.9$,

0.8 for 6 consecutive mo

Not reported

Participants attended mean of 5 peer support meetings; 18\% never attended a meeting

First month, average of 4 calls/mo; by 6 mo, average of 2 calls/mo

Not reported

Average of 5.03 calls per participant by peer supporter lasting approximately 25-30 min

Median of 5 (range $=0$-29) interactions with the peer health coach

123 patients (83\%) had at least 1 interaction; most interactions $(76.6 \%)$ were by telephone, and the remainder were in person

Median of 20 calls per patient

61.5\% participants attended at least 1 education session; most participants had telephone or e-mail contacts with peers

Mean number of group attendances: 3.7 
Table 1. Descriptive Summary of the Characteristics of Included Studies (continued)

\begin{tabular}{|c|c|c|c|c|}
\hline Study, Year & $\begin{array}{l}\text { Patients, } \\
\text { No. }\end{array}$ & Setting, Population & Intervention & Control \\
\hline $\begin{array}{l}\text { Safford et al, }{ }^{28} \\
2015\end{array}$ & 424 & $\begin{array}{l}\text { United States: cluster ran- } \\
\text { domized trial; African } \\
\text { American }>90 \% \\
\text { Mean } \mathrm{HbA}_{1 \mathrm{c}} 7.9 \%\end{array}$ & $\begin{array}{l}\text { Same as control and initial } 45-60-\text { min in-per- } \\
\text { son or telephone get-to-know session with } \\
\text { peer supporter followed by weekly calls for } \\
2 \text { mo followed by monthly calls for } 8 \text { mo }\end{array}$ & $\begin{array}{l}1 \text { h of group diabetes } \\
\text { education class, } 5 \text {-min } \\
\text { counseling session, and } \\
\text { diabetes report card }\end{array}$ \\
\hline $\begin{array}{l}\text { Ayala et al, }{ }^{21} \\
2015\end{array}$ & 336 & $\begin{array}{l}\text { United States: predominantly } \\
\text { Hispanic } \\
\text { Mean } \mathrm{HbA}_{1 \mathrm{c}} 8.7 \%\end{array}$ & $\begin{array}{l}8 \text { telephone or in-person contacts with peer } \\
\text { supporter in first } 6 \mathrm{mo} \text {, then as needed con- } \\
\text { tacts in the last } 6 \mathrm{mo} ; 92 \% \text { of participants } \\
\text { had telephone contacts } \\
5-8 \text { patients per peer leader }\end{array}$ & Usual care \\
\hline $\begin{array}{l}\text { McGowan, }{ }^{35} \\
2015\end{array}$ & 361 & $\begin{array}{l}\text { Canada: race/ethnicity not } \\
\text { given } \\
\text { Mean } \mathrm{HbA}_{1 \mathrm{c}} 7.19 \%\end{array}$ & $\begin{array}{l}\text { Two participant groups received } 2 \text { varied } \\
\text { types of peer-led self- management pro- } \\
\text { grams with varying components: weekly } \\
\text { meetings for } 6 \text { wk }\end{array}$ & Usual care \\
\hline
\end{tabular}

$\mathrm{CDE}=$ certified diabetes educator; $\mathrm{HbA}_{1 \mathrm{c}}=$ hemoglobin $\mathrm{A}_{1 \mathrm{c}}$.

ment at baseline. The pooled effect from these studies showed no improvement in $\mathrm{HbA}_{1 \mathrm{c}}$ level with peer support interventions, with an SMD of 0.041 (95\% $\mathrm{CI},-0.072$ to $0.153 ; P=.47 ; \mathrm{I}^{2}=.00 \%$ ) (Supplemental Appendix Figure A3, http://www.annfammed.org/content/14/6/540/suppl/DC1). In the 12 studies in which

\section{Table 2. Quality of the Included Studies Assessed With the Cochrane Risk of Bias Tool ${ }^{12}$}

\begin{tabular}{|c|c|c|c|c|}
\hline Study, Year & $\begin{array}{l}\text { Adequate } \\
\text { Sequence } \\
\text { Generation }\end{array}$ & $\begin{array}{c}\text { Allocation } \\
\text { Concealment }\end{array}$ & $\begin{array}{c}\text { Blinding of } \\
\text { Investigators } \\
\text { and/or Outcome } \\
\text { Assessors }\end{array}$ & $\begin{array}{l}\text { Complete } \\
\text { Outcome } \\
\text { Data }\end{array}$ \\
\hline $\begin{array}{l}\text { Keyserling et al, }{ }^{23} \\
2002\end{array}$ & Yes & Yes & No & Yes \\
\hline Lorig et al, 262008 & Yes & $Y_{e s}^{a}$ & No & Yes \\
\hline Lorig et al, 252009 & Yes & Yes $^{\mathrm{a}}$ & No & Yes \\
\hline Dale et al, ${ }^{32} 2009$ & Yes & Yes & No & Yes \\
\hline Cade et al, ${ }^{31} 2009$ & Yes $^{b}$ & $\mathrm{No}^{c}$ & $\mathrm{No}^{\mathrm{c}}$ & Yes \\
\hline Heisler et al, ${ }^{22} 2010$ & Yes & Yes & Yes & Yes \\
\hline $\begin{array}{l}\text { Philis-Tsimikas et al, }{ }^{27} \\
2011\end{array}$ & Yes & Yes $^{a}$ & $\mathrm{No}^{\mathrm{a}}$ & Yes \\
\hline Smith et al, ${ }^{34} 2011$ & Yes & Yes & No & Yes \\
\hline Long et al, ${ }^{24} 2012$ & Yes & Yes & Yes & Yes \\
\hline $\begin{array}{l}\text { Gagliardino et al, } \\
2013\end{array}$ & $Y^{a}{ }^{a}$ & $\mathrm{No}^{c}$ & $\mathrm{No}^{\mathrm{c}}$ & $\mathrm{No}^{\mathrm{c}}$ \\
\hline Siminerio et al, 2013 & Yes & $\mathrm{No}^{\mathrm{a}}$ & No & Yes \\
\hline Thom et $\mathrm{al}_{,}{ }^{30} 2013$ & Yes & Yes & $\mathrm{No}^{\mathrm{a}}$ & Yes \\
\hline Chan et al, ${ }^{36} 2014$ & Yes & Yes & $\mathrm{No}^{\mathrm{c}}$ & Yes \\
\hline Simmons et al, 2015 & Yes & Yes & Yes & Yes \\
\hline Safford et al, ${ }^{28} 2015$ & Yes & Yes & No & Yes \\
\hline Ayala et al, ${ }^{21} 2015$ & Yes & $\mathrm{No}^{c}$ & $\mathrm{No}^{c}$ & Yes \\
\hline McGowan, ${ }^{35} 2015$ & Yes & Yes & No & Yes \\
\hline \multicolumn{5}{|c|}{$\begin{array}{l}\text { Notes: Yes indicates low risk of bias; No indicates high risk of bias. Selective outcome reporting risk was consid- } \\
\text { ered minimal as we selected only studies that reported hemoglobin } A_{1} \text { level as the outcome. No other major } \\
\text { biases were noted in the included studies. None of the trials blinded participants. }\end{array}$} \\
\hline \multicolumn{5}{|c|}{ a Author response to information requests. } \\
\hline \multicolumn{5}{|c|}{ b Likely low risk of bias but no details on sequence generation available from article and author. } \\
\hline
\end{tabular}

control groups received usual care, however, peer support interventions led to a significant improvement in $\mathrm{HbA}_{1 \mathrm{c}}$ level, with an SMD of $0.147(95 \% \mathrm{CI}$, $\left.0.021-0.273{ }_{i} P=.02{ }_{i} \mathrm{I}^{2}=70.53 \%\right)$, which translates to an improvement in $\mathrm{HbA}_{1 \mathrm{c}}$ level of $0.29 \%$ (95\% CI, 0.04\%-0.54\%). The between-group differences in subgroups by baseline intervention, however, was nonsignificant, with $P=.22$. There was no difference in improvement in $\mathrm{HbA}_{1 \mathrm{c}}$ level among subgroups based on the method used to deliver the peer intervention (group education, telephone delivery, or a combination of both) (Supplemental Appendix Figure A4, http://www.annfammed.org/content/14/6/540/ suppl/DC1). The pooled effect of 11 studies using peer supervision as defined in the data extraction section showed a significant improvement in $\mathrm{HbA}_{1 \mathrm{c}}$ level with peer support interventions, with an SMD of 0.143 (95\% CI, 0.050-0.237; $P=.003 ; I^{2}=43.25 \%$, which translates to an improvement in $\mathrm{HbA}_{1 \mathrm{c}}$ level of $0.28 \%(95 \%$ CI, $0.099 \%-0.47 \%)$. In contrast, the pooled effect from 8 studies without peer supervision did not show an improvement in $\mathrm{HbA}_{\mathrm{lc}}$ level with peer support interventions, with an SMD of $0.078(95 \% \mathrm{CI},-0.157$ to $\left.0.31{ }_{i} P=.52 ; \mathrm{I}^{2}=77.09 \%\right)$, and 
Duration of Peer Training

12 h over $2 \mathrm{~d}$

40-50 h
Peer Supervision

Contacts documented on forms and random contacts with intervention participants

Contact logs maintained and tracked by peer leader coordinator

Session attendance was logged
Attendance Rates, Intensity

Mean number of contacts: 13.3 (SD, 8.1)

$8.3 \%$ of participants had no contacts

Median number of contacts per participant: 4 (range $=1-24)$

$7 \%$ received no intervention

Mean attendance for intervention group: 5 sessions there was a nonsignificant between-group $P$ value of 61 (Appendix Figure A5, http://www.annfammed.org/ content/14/6/540/suppl/DC1).

\section{Self-Efficacy Outcomes}

Six studies measured self-efficacy outcomes using diverse scales; hence, the interaction between these

Figure 2. Effect of peer support interventions on hemoglobin $A_{1 c}$ levels.

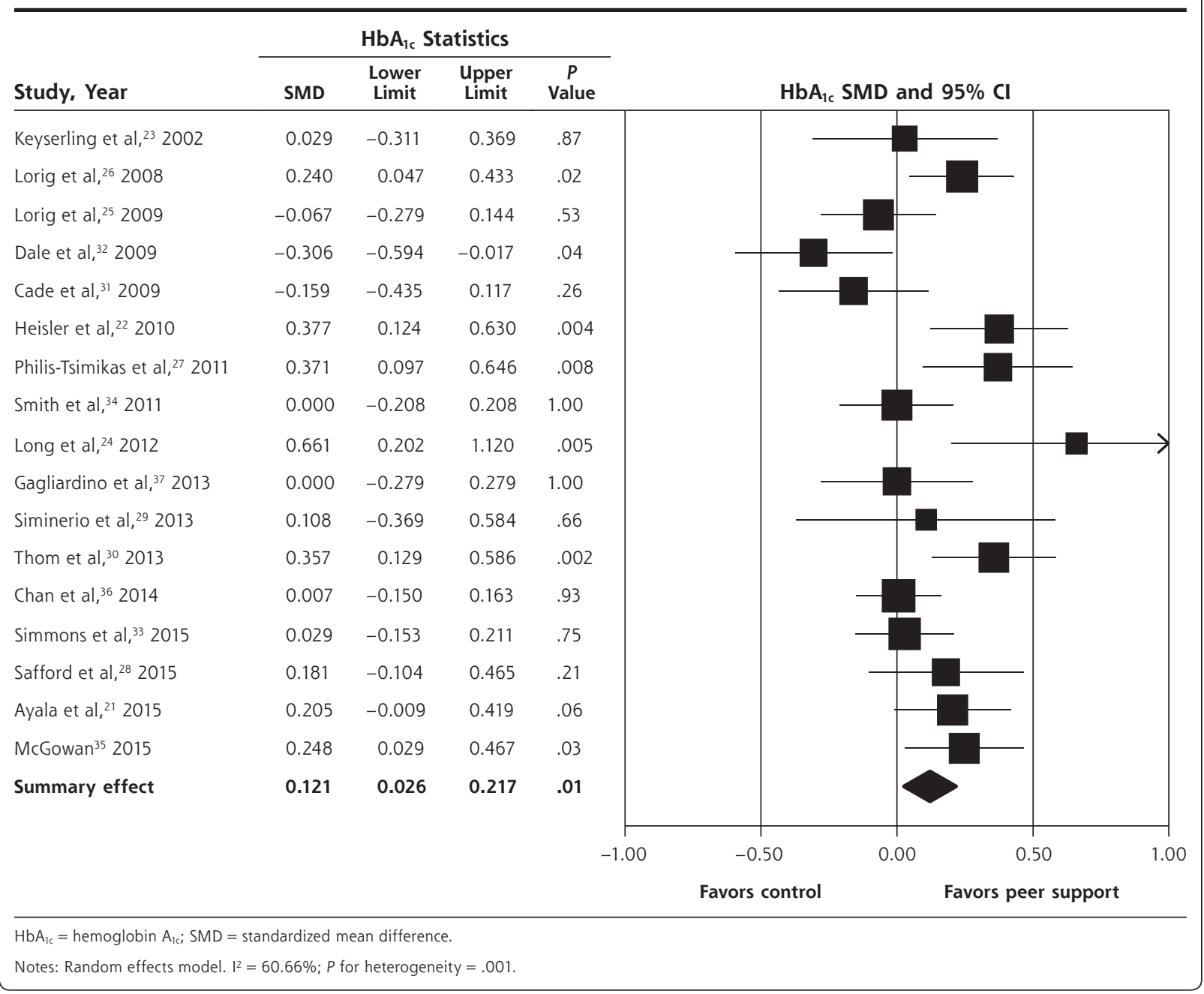


outcomes and $\mathrm{HbA}_{1 \mathrm{c}}$ levels could not be summarized quantitatively. Two of the 3 studies that showed a significant improvement in self-efficacy outcomes with peer support interventions also showed an improvement in $\mathrm{HbA}_{1 \mathrm{c}}$ level with these interventions. ${ }^{25,26,35}$ Three studies that did not show any significant improvements in self-efficacy outcomes with peer support interventions did not demonstrate improvements in $\mathrm{HbA}_{1 \mathrm{c}}$ levels with the interventions. ${ }^{31-33}$

Metaregression analysis did not show any interaction between the duration of peer training in hours (Supplemental Appendix Figure A6, http://www.annfammed. org/content/14/6/540/suppl/DC1), mean participant baseline $\mathrm{HbA}_{1 \mathrm{c}}$ level (Supplemental Appendix Figure A7, http://www.annfammed.org/content/14/6/540/suppl/ DC1), and the duration of observation (Supplemental Appendix Figure A8, http://www.annfammed.org/content/14/6/540/suppl/DC1) on the change in $\mathrm{HbA}_{1 \mathrm{c}}$ level between the intervention and control groups.

\section{DISCUSSION}

Our results show that peer support interventions delivered by people affected by diabetes are associated with a small but statistically significant reduction in $\mathrm{HbA}_{1 \mathrm{c}}$ level of $0.24 \%$ (95\% CI, $0.05 \%-0.43 \%)$. This finding

Figure 3. Subgroup analysis of the effect of peer support interventions on hemoglobin $A_{1 c}$ levels in studies by predominant race/ethnicity of the participants.

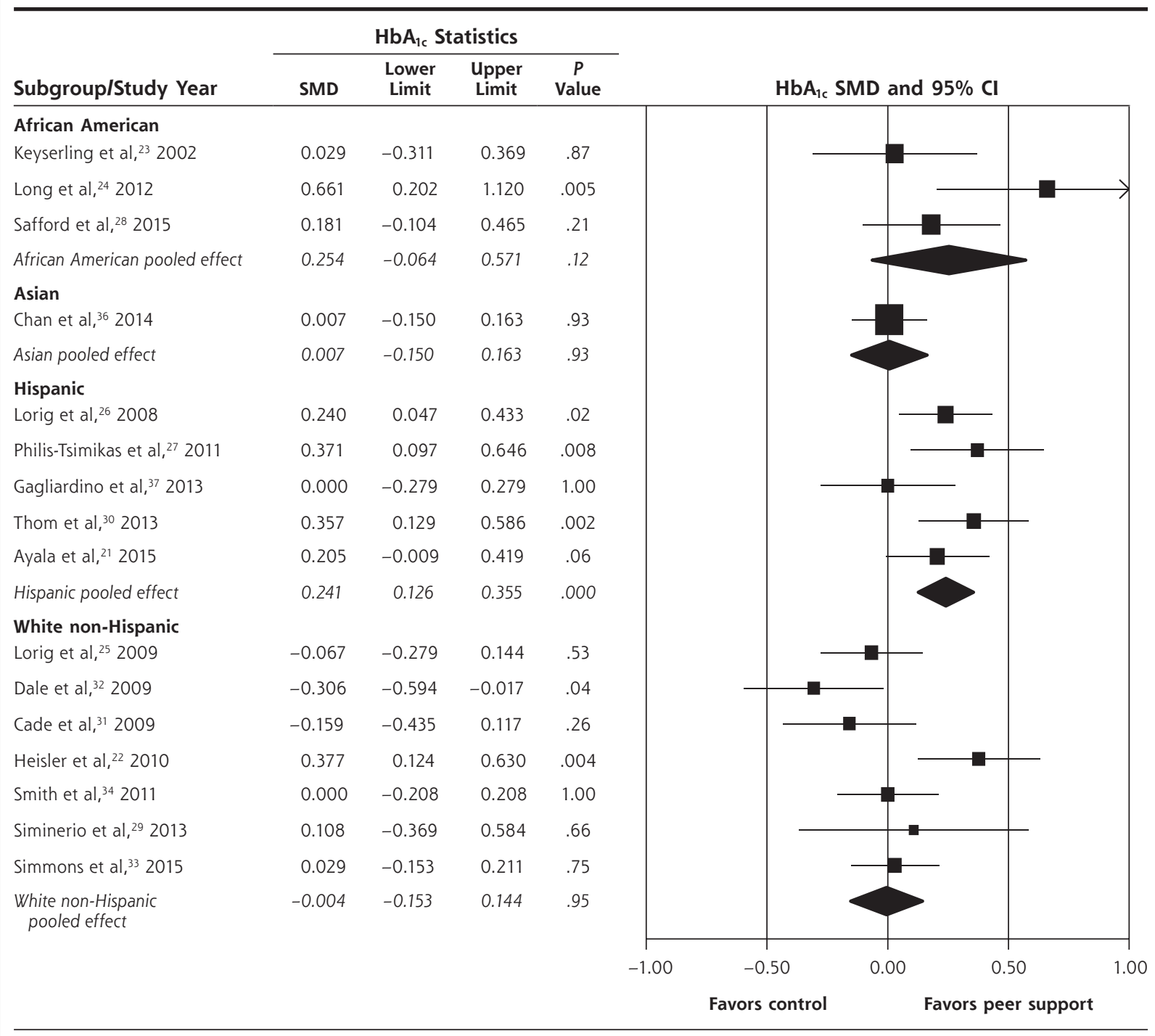

$\mathrm{HbA}_{\mathrm{lc}}=$ hemoglobin $\mathrm{A}_{\mathrm{lc}}$ S SMD = standardized mean difference.

Notes: African American subgroup: $I^{2}=58.60 \%, P$ for heterogeneity $=.08$. Asian subgroup: $I^{2}=0.00 \%$. Hispanic subgroup: $I^{2}=17.12 \%, P$ for heterogeneity $=.30$. White non-Hispanic subgroup: $I^{2}=59.41 \%, P$ for heterogeneity $=.02$. 
is comparable to that of a recent Cochrane systematic review and meta-analysis of personalized care planning between clinicians and patients that led to a pooled reduction in $\mathrm{HbA}_{1 \mathrm{c}}$ level of $0.24 \%$ (95\% CI, $0.14 \%$ $0.35 \%) .{ }^{38}$ We found that the effect was more clinically relevant in studies with predominantly minority participants, particularly Hispanic participants. A 2014 Cochrane review showed that glycemic control and knowledge of diabetes are improved when culturally appropriate health education is provided to people with diabetes who belong to ethnic minority groups. ${ }^{39}$ Peer health coaches might be providing more culturally appropriate health education in ethnic minority populations, particularly Latino ones.

Of the 5 studies with predominantly Hispanic populations, 4 were done in the United States and 1 in Argentina. The last was the only one in the subgroup that did not show any effect of peer support interven- tions on $\mathrm{HbA}_{1 \mathrm{c}}$ levels. This finding encouraged us to look at the subgroup of studies with predominantly minority and nonminority participants based on country of residence.

Caution is needed in interpreting results from the 3 studies done with predominantly African American participants, as these studies had diverse characteristics; 1 study showed improvement in $\mathrm{HbA}_{1 \mathrm{c}}$ level with peer support interventions whereas the other 2 did not. Additional trials with African American participants may further define the effect of peer support interventions in this subgroup. In our analysis, the existing intervention approaches and dosages did not appear to be effective in white non-Hispanic populations, although with moderate heterogeneity of results. A previous subgroup analysis and secondary analysis of RCTs showed that peer support interventions for patients with diabetes are most effective for those having poor self-management

Figure 4. Subgroup analysis of the effect of peer support interventions on hemoglobin $A_{1 c}$ levels in studies by predominant minority status of the participants.

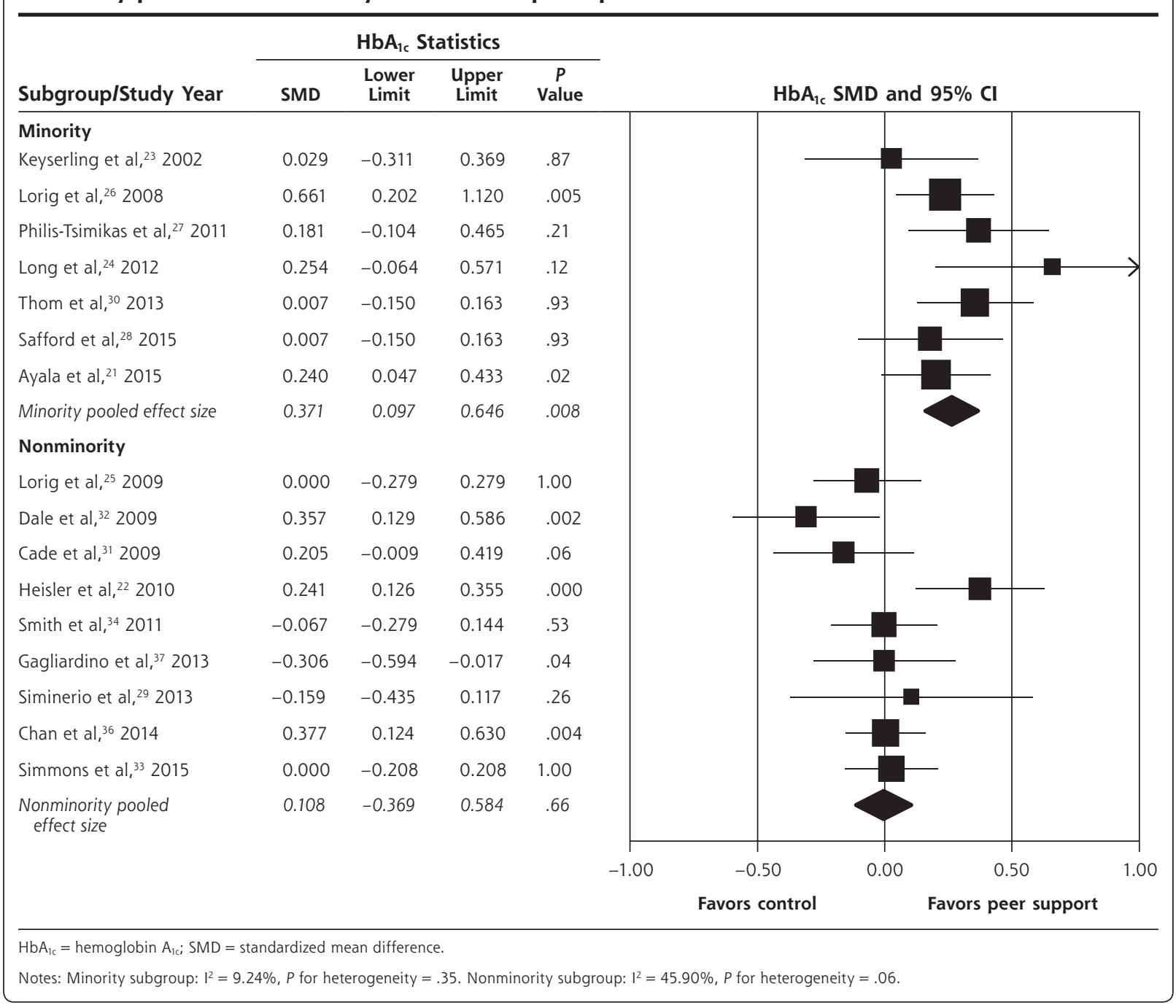


skills, poor baseline diabetes support, and lower levels of health literacy. ${ }^{40,41}$ Further innovative studies of interventions that sustain self-management behaviors in white non-Hispanic populations targeting high-risk groups with the above-noted characteristics need to be done.

Our subgroup analyses also show that peer support did not produce additional improvement in $\mathrm{HbA}_{1 \mathrm{c}}$ levels when both groups received care management or group education sessions. Other studies comparing similar interventions delivered by peer supporters and other health professionals or community health workers found no significant difference in glycemic control. ${ }^{42-44}$ In resource-constrained health care settings where care management is not feasible for a larger patient population, peer support interventions might be an effective way of improving diabetes outcomes. Although we were not able to perform a quantitative assessment of the interaction of self-efficacy outcomes and $\mathrm{HbA}_{1 \mathrm{c}}$ outcomes because of the heterogeneity of assessment methods, our qualitative assessment showed that most trials in which peer support improved self-efficacy, $\mathrm{HbA}_{1 \mathrm{c}}$ level improved as well, and conversely, trials without a gain in self-efficacy had no improvement in $\mathrm{HbA}_{1 \mathrm{c}}$ level. It may be that the peer support affects glycemic control through increased self-efficacy.

Our study has limitations. Although significant, the overall improvement in $\mathrm{HbA}_{1 \mathrm{c}}$ level with peer support interventions was small in terms of clinical relevance. Additionally, $\mathrm{HbA}_{1 \mathrm{c}}$ level, an intermediate biochemical marker, was the outcome assessed instead of patientcentered outcomes or clinical outcomes that take years to become apparent. We chose $\mathrm{HbA}_{1 \mathrm{c}}$ level because of the lack of studies reporting those outcomes and the generally short duration of follow-up in most studies. Even though all the included studies were RCTs, participants were not blinded, but blinding would be impossible where participants had to interact with the peer supporters for intervention delivery. Our subgroup analyses showed qualitative interaction between effect sizes and directions for various subgroups; nevertheless, these comparisons were post hoc. ${ }^{45,46}$ Additionally, meta-analysis of individual patient data would be much better for understanding the subgroup differences than the group-level differences in demographics used in our analysis. Another limitation was that we could not assess the interaction of socioeconomic status with the effect of peer support interventions or estimate costeffectiveness as there was not enough information given. The included studies were conducted in diverse settings and populations, but most took place in the United States and Europe, which may limit generalizability.

In conclusion, peer support interventions modestly improved $\mathrm{HbA}_{1 \mathrm{c}}$ level, with greatest improvement in studies with predominantly minority participants.
Future research should include high-quality trials assessing the effect of peer support interventions on long-term patient-centered outcomes.

To read or post commentaries in response to this article, see it online at http://www.annfammed.org/content/14/6/540.

Key words: peer support; support groups; diabetes mellitus; glycemic control; hemoglobin $A_{1 c i}$ self-efficacy

Submitted February 2, 2016; submitted, revised, May 26, 2016; accepted June 2, 2016.

Funding support: This study was funded by internal funding from the University of Missouri, Department of Family and Community Medicine.

Previous presentation: Some of the findings from this article were presented in 2015 at the North American Primary Care Research Group (NAPCRG) conference, October 24-28, 2015; Cancun, Mexico.

Acknowledgments: The authors would like to acknowledge the editorial assistance of Gaia Guirl-Stearley while preparing the manuscript.

Supplementary materials: Available at http://www.AnnFamMed. org/content/14/6/540/suppl/DC1/.

\section{References}

1. Guariguata L, Whiting DR, Hambleton I, Beagley J, Linnenkamp $U$, Shaw JE. Global estimates of diabetes prevalence for 2013 and projections for 2035. Diabetes Res Clin Pract. 2014;103(2):137-149.

2. Strawbridge LM, Lloyd JT, Meadow A, Riley GF, Howell BL. Use of Medicare's diabetes self-management training benefit. Health Educ Behav. 2015:42(4):530-538.

3. Duncan I, Ahmed T, Li QE, et al. Assessing the value of the diabetes educator. Diabetes Educ. 2011;37(5):638-657.

4. Li R, Shrestha SS, Lipman R, Burrows NR, Kolb LE, Rutledge S; Centers for Disease Control and Prevention (CDC). Diabetes selfmanagement education and training among privately insured persons with newly diagnosed diabetes-United States, 2011-2012. MMWR Morb Mortal Wkly Rep. 2014;63(46):1045-1049.

5. Norris SL, Lau J, Smith SJ, Schmid CH, Engelgau MM. Selfmanagement education for adults with type 2 diabetes: a metaanalysis of the effect on glycemic control. Diabetes Care. 2002;25 (7):1159-1171.

6. World Health Organization. Peer Support Programmes in Diabetes: Report of a WHO Consultation. Geneva, Switzerland: World Health Organization; 2008. http://www.who.int/diabetes/publications/Diabetes_final_13_6.pdf. Accessed Mar 20, 2015.

7. Dale JR, Williams SM, Bowyer V. What is the effect of peer support on diabetes outcomes in adults? A systematic review. Diabet Med. 2012;29(11):1361-1377.

8. Qi L, Liu Q, Qi X, Wu N, Tang W, Xiong H. Effectiveness of peer support for improving glycaemic control in patients with type 2 diabetes: a meta-analysis of randomized controlled trials. BMC Public Health. 2015;15:471.

9. Peers for Progress. What is peer support? http://peersforprogress. org/learn-about-peer-support/what-is-peer-support/. Accessed Jul 28, 2015.

10. Goldman ML, Ghorob A, Eyre SL, Bodenheimer T. How do peer coaches improve diabetes care for low-income patients? A qualitative analysis. Diabetes Educ. 2013;39(6):800-810.

11. Liberati A, Altman DG, Tetzlaff J, et al. The PRISMA statement for reporting systematic reviews and meta-analyses of studies that evaluate health care interventions: explanation and elaboration. Ann Intern Med. 2009;151(4):W65-W94. 
12. Higgins JPT, Altman DG, Sterne JAC. Chapter 8: Assessing risk of bias in included studies. In: Higgins JPT, Green S, eds. Cochrane Handbook for Systematic Reviews of Interventions. Version 5.1.0. Oxford, England: Cochrane Collaboration; 2011. http://handbook. cochrane.org/chapter_8/8_assessing_risk_of_bias_in_included_studies.htm. Accessed Jan 20, 2016.

13. DerSimonian R, Laird N. Meta-analysis in clinical trials. Control Clin Trials. 1986;7(3):177-188.

14. Lipsey MW, Wilson DB. Practical Meta-Analysis. Thousand Oaks, CA: Sage Publications; 2001.

15. Higgins JPT, Deeks JJ, Altman DG. Section 16.3.4: Approximate analyses of cluster-randomized trials for a meta-analysis: effective sample sizes. In: Higgins JPT, Green S, eds. Cochrane Handbook for Systematic Reviews of Interventions. Version 5.1.0. Oxford, England: Cochrane Collaboration; 2011. http://handbook.cochrane.org/chapter_16/16_3_4_approximate_analyses_of_cluster_randomized_trials_for_a.htm. Accessed Jan 20, 2016.

16. Follmann D, Elliott P, Suh I, Cutler J. Variance imputation for overviews of clinical trials with continuous response. J Clin Epidemiol. 1992;45(7):769-773.

17. Deeks JJ, Higgins JPT, Altman DG. Section 9.5.2: Identifying and measuring heterogeneity. In: Higgins JPT, Green S, eds. Cochrane Handbook for Systematic Reviews of Interventions. Version 5.1.0. Oxford, England: Cochrane Collaboration; 2011. http://handbook. cochrane.org/chapter_9/9_5_2_identifying_and_measuring_heterogeneity.htm. Accessed Jan 20, 2016.

18. Deeks JJ, Higgins JPT, Altman DG. Section 9.6.3.1: Is the effect different in different subgroups? In: Higgins JPT, Green S, eds. Cochrane Handbook for Systematic Reviews of Interventions. Version 5.1.0. Oxford, England: Cochrane Collaboration; 2011. http:// handbook.cochrane.org/chapter_9/9_6_3_1_is_the_effect_different_in_different_subgroups.htm. Accessed Jan 20, 2016.

19. Egger M, Davey Smith G, Schneider M, Minder C. Bias in metaanalysis detected by a simple, graphical test. BMJ. 1997;315(7109): 629-634.

20. Moher D, Liberati A, Tetzlaff J, Altman DG; PRISMA Group. Preferred Reporting Items for Systematic Reviews and Meta-Analyses: the PRISMA statement. PLoS Med. 2009;6(7):e1000097.

21. Ayala GX, Ibarra L, Cherrington AL, et al. Puentes hacia una mejor vida (Bridges to a better life): outcome of a diabetes control peer support intervention. Ann Fam Med. 2015;13(Suppl 1):S9-S17.

22. Heisler M, Vijan S, Makki F, Piette JD. Diabetes control with reciprocal peer support versus nurse care management: a randomized trial. Ann Intern Med. 2010;153(8):507-515.

23. Keyserling TC, Samuel-Hodge CD, Ammerman AS, et al. A randomized trial of an intervention to improve self-care behaviors of African-American women with type 2 diabetes: impact on physical activity. Diabetes Care. 2002;25(9):1576-1583.

24. Long JA, Jahnle EC, Richardson DM, Loewenstein G, Volpp KG. Peer mentoring and financial incentives to improve glucose control in African American veterans: a randomized trial. Ann Intern Med. 2012;156(6):416-424.

25. Lorig K, Ritter PL, Villa FJ, Armas J. Community-based peer-led diabetes self-management: a randomized trial. Diabetes Educ. 2009;35 (4):641-651.

26. Lorig K, Ritter PL, Villa F, Piette JD. Spanish diabetes selfmanagement with and without automated telephone reinforcement: two randomized trials. Diabetes Care. 2008;31(3):408-414.

27. Philis-Tsimikas A, Fortmann A, Lleva-Ocana L, Walker C, Gallo LC. Peer-led diabetes education programs in high-risk Mexican Americans improve glycemic control compared with standard approaches: a Project Dulce promotora randomized trial. Diabetes Care. 2011;34(9):1926-1931.

28. Safford MM, Andreae S, Cherrington AL, et al. Peer coaches to improve diabetes outcomes in rural Alabama: a cluster randomized trial. Ann Fam Med. 2015;13(Suppl 1):S18-S26.

29. Siminerio L, Ruppert KM, Gabbay RA. Who can provide diabetes self-management support in primary care? Findings from a randomized controlled trial. Diabetes Educ. 2013;39(5):705-713.
30. Thom DH, Ghorob A, Hessler D, De Vore D, Chen E, Bodenheimer TA. Impact of peer health coaching on glycemic control in lowincome patients with diabetes: a randomized controlled trial. Ann Fam Med. 2013;11(2):137-144.

31. Cade JE, Kirk SF, Nelson P, et al. Can peer educators influence healthy eating in people with diabetes? Results of a randomized controlled trial. Diabet Med. 2009;26(10):1048-1054.

32. Dale J, Caramlau I, Sturt J, Friede T, Walker R. Telephone peerdelivered intervention for diabetes motivation and support: the telecare exploratory RCT. Patient Educ Couns. 2009;75(1):91-98.

33. Simmons D, Prevost AT, Bunn C, et al. Impact of community based peer support in type 2 diabetes: a cluster randomised controlled trial of individual and/or group approaches. PLoS One. 2015;10(3): e0120277.

34. Smith SM, Paul G, Kelly A, Whitford DL, O'Shea E, O'Dowd T. Peer support for patients with type 2 diabetes: cluster randomised controlled trial. BMJ. 2011;342:d715.

35. McGowan P. The relative effectiveness of self-management programs for type 2 diabetes. Can J Diabetes. 2015;39(5):411-419.

36. Chan JC, Sui Y, Oldenburg B, et al.; JADE and PEARL Project Team. Effects of telephone-based peer support in patients with type 2 diabetes mellitus receiving integrated care: a randomized clinical trial. JAMA Intern Med. 2014;174(6):972-981.

37. Gagliardino JJ, Arrechea V, Assad D, et al. Type 2 diabetes patients educated by other patients perform at least as well as patients trained by professionals. Diabetes Metab Res Rev. 2013;29(2):152-160.

38. Coulter A, Entwistle VA, Eccles A, Ryan S, Shepperd S, Perera R. Personalised care planning for adults with chronic or long-term health conditions. Cochrane Database Syst Rev. 2015;3(3):CD010523.

39. Attridge M, Creamer J, Ramsden M, Cannings-John R, Hawthorne K. Culturally appropriate health education for people in ethnic minority groups with type 2 diabetes mellitus. Cochrane Database Syst Rev. 2014;9(9):CD006424.

40. Moskowitz D, Thom DH, Hessler D, Ghorob A, Bodenheimer T. Peer coaching to improve diabetes self-management: which patients benefit most? J Gen Intern Med. 2013;28(7):938-942.

41. Piette JD, Resnicow K, Choi H, Heisler M. A diabetes peer support intervention that improved glycemic control: mediators and moderators of intervention effectiveness. Chronic IIIn. 2013;9(4):258-267.

42. Baksi AK, Al-Mrayat M, Hogan D, Whittingstall E, Wilson P, Wex J. Peer advisers compared with specialist health professionals in delivering a training programme on self-management to people with diabetes: a randomized controlled trial. Diabet Med. 2008;25(9): 1076-1082.

43. Baghianimoghadam MH, Hadavandkhani M, Mohammadi M, Fallahzade H, Baghianimoghadam B. Current education versus peereducation on walking in type 2 diabetic patients based on Health Belief Model: a randomized control trial study. Rom J Intern Med. 2012;50(2):165-172.

44. Tang TS, Funnell M, Sinco B, et al. Comparative effectiveness of peer leaders and community health workers in diabetes selfmanagement support: results of a randomized controlled trial. Diabetes Care. 2014;37(6):1525-1534.

45. Deeks JJ, Higgins JPT, Altman DG. Section 9.6.6: Interpretation of subgroup analyses and meta-regressions. In: Higgins JPT, Green S, eds. Cochrane Handbook for Systematic Reviews of Interventions. Version 5.1.0. Oxford, England: Cochrane Collaboration; 2011. http:// handbook.cochrane.org/chapter_9/9_6_6_interpretation_of_subgroup_analyses_and_meta_regressions.htm. Accessed Jan 20, 2016.

46. Deeks JJ, Higgins JPT, Altman DG. Section 9.6.2: What are subgroup analyses? In: Higgins JPT, Green S, eds. Cochrane Handbook for Systematic Reviews of Interventions. Version 5.1.0. Oxford, England: Cochrane Collaboration; 2011. http://handbook.cochrane.org/ chapter_9/9_6_2_what_are_subgroup_analyses.htm. Accessed Jan 20, 2016. 